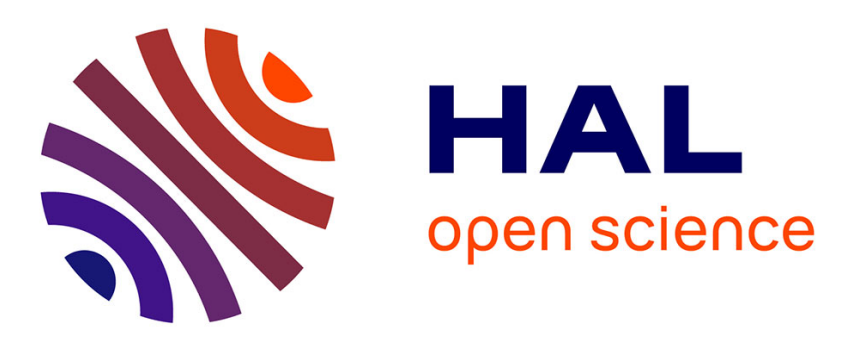

\title{
Reply to J.W. Van Hoorn "Some observations with respect to sodicity hazard of irrigation waters"
}

Laurent Barbiero, Vincent Vallès, Claude Cheverry

\section{To cite this version:}

Laurent Barbiero, Vincent Vallès, Claude Cheverry. Reply to J.W. Van Hoorn "Some observations with respect to sodicity hazard of irrigation waters". Agricultural Water Management, 2004, 68, pp.177-184. hal-00364716

\section{HAL Id: hal-00364716 https://hal.science/hal-00364716}

Submitted on 26 Feb 2009

HAL is a multi-disciplinary open access archive for the deposit and dissemination of scientific research documents, whether they are published or not. The documents may come from teaching and research institutions in France or abroad, or from public or private research centers.
L'archive ouverte pluridisciplinaire HAL, est destinée au dépôt et à la diffusion de documents scientifiques de niveau recherche, publiés ou non, émanant des établissements d'enseignement et de recherche français ou étrangers, des laboratoires publics ou privés. 


\title{
Letter to the Editor \\ Reply to J.W. Van Hoorn "Some observations with respect to sodicity hazard of irrigation waters"
}

\author{
Laurent Barbiéro $^{1}$, Vincent Valles ${ }^{2}$, Claude Cheverry ${ }^{3}$ \\ ${ }^{1}$ IFCWS, Indian Institute of Science, Department of Civil Engineering, 560012 Bangalore, India. \\ e-mail: barbiero@civil.iisc.ernet.in (IRD-UR 154, UMR 5563). \\ ${ }^{2}$ Laboratoire Chimie et Environnement, Case 29 Université de Provence (Aix-Marseille I), 3 Place Victor Hugo \\ 13331 Marseille Cedex 03, France. \\ 3- ENSA-INRA, Unité de Sciences du Sol et d'Agronomie de Rennes /Quimper, 65 rue de St Brieuc, 35042 \\ Rennes Cedex, France.
}

In the comments "Some observations with respect to sodicity hazard of irrigation waters", Dr. Van Hoorn opened a constructive discussion about the assessment of sodicity hazard of soils subjected to irrigation in arid or semi arid areas. The following are three concepts usually used for the afore mentioned assessment, which are reminded in his comment on our article:

- The Sodium Adsorption Ratio, SAR $=\mathrm{Na} /((\mathrm{Ca}+\mathrm{Mg}) / 2)^{1 / 2}$ in eq.. $\mathrm{L}^{-1}$, (Richards, 1954).

- The adjusted SAR, SAR adj $_{1}$ SAR $(1+(8.4-\mathrm{pHc}))$, (Suarez, 1981; Ayers and Westcot, 1985)

- $\quad$ The Residual Sodium Carbonate, RSC = Alk. $-\mathrm{Ca}-\mathrm{Mg}$ in eq. $\mathrm{L}^{-1}$ (Eaton, 1950; Richards, 1954)

We identified two major points in Dr's Van Hoorn comments. The first one deals with the assessment of the chemical quality of the water used in Niger with respect to soil sodization hazard (Barbiéro et al., 2001). Indeed, the sodicity hazard is low, low-moderate, or very high according to the SAR, the $\mathrm{SAR}_{\mathrm{adj}}$, or the RSC respectively. Therefore, the donors face with a difficult choice in developing new irrigation schemes in Niger valley. Dr. Van Hoorn concludes that the RSC is the most suitable indicator for the assessment of sodicity hazard of Niger irrigation water.

With the second point Dr. Van Hoorn is considering if the process of magnesium precipitation should be taken into account for the assessment of sodicity hazard. Both questions will be answered successively.

\section{The SAR :}

This SAR concept, which is generally used as a reliable indication for the assessment of water quality, presents two major problems:

1. The assessment of sodicity hazard from the SAR has been established empirically from data collected mainly in North America (Richards, 1954) from waters evolving through the saline way under the influence of evaporation (Cheverry, 1974). These waters exhibit a negative calcite residual alkalinity $\left(\mathrm{RA}_{\text {calcite }}<0\right)$, and the sodicity hazard is practically nil in this scenario. On the other hand, the sodicity hazard is real in places such as Niger where the irrigation waters evolve through the alkaline way (Cheverry, 1974) and exhibit a positive calcite residual alkalinity $\left(\mathrm{RA}_{\text {calcite }}>0\right)$. Therefore, in the last case, the use of the SAR concept leads to a wide underestimation of the sodicity hazard, as observed for the irrigation water used in the Niger valley in Mali (Valles et al., 1989) or Niger (Barbiéro et al., 1995).

2. The assessment of sodicity hazard from the SAR is a static view of the problem that do not take into account the changes in the water chemistry due to concentration by evaporation. This is illustrated in Fig. 1, where the evolution of both SAR and Electrical Conductivity of three types of water during a pan evaporation experiment are plotted. The 
data were taken from Valles (1987) in the Medjerdah valley in Tunisia, Gonzalez-Barrios (1992) in the Comarca Lagunera in Mexico, and Barbiéro (1995) in Niger. On the Tunisian site, the sodicity hazard remains low during the evaporation. For the Mexican water, it increases slowly and reaches the second class (moderate sodicity hazard) with the higher concentration factors. Finally, in Niger the sodicity hazard increases strongly and reaches dangerous levels even while at the moderate concentration factors. Thus, the three irrigation waters present the same soil sodization hazard but evolve in three different ways, hence, emphasizing the limitation of the SAR concept.

\section{The adjusted SAR :}

The concept of Adjusted SAR, used for carbonate waters, is a first step towards a dynamic view of sodicity hazard assessment during the evaporation and concentration, although it remains inadequate.

Considering the precipitation of a mineral $\mathrm{AB}$ according to the reaction :

$$
\mathrm{A}+\mathrm{B} \leftarrow \mathrm{AB}
$$

The equilibrium between the solute $\mathrm{A}, \mathrm{B}$ and the mineral $\mathrm{AB}$ is governed by the equation :

$$
\text { (A) . (B) } /(\mathrm{AB})=\mathrm{K}
$$

Where $\mathrm{K}$ is the constant of solubility and ( ) denote the activities. The activity of the crystal $\mathrm{AB}$ is conventionally equal to 1 , the relation is :

Taking the Log of this equation, we have :

$$
\text { (A) } .(\mathrm{B})=\mathrm{K}
$$

$$
\log (\mathrm{A})+\log (\mathrm{B})=\log (\mathrm{K})
$$

Therefore, the equilibrium is represented by a negative unit-slope line in the diagram $\log (\mathrm{A})$ versus $\log (\mathrm{B})$ (Fig. 2). For a diluted solution, the product (A).(B) is below $\mathrm{K}$. When the solution concentrates, the equilibrium is reached and the product (A).(B) becomes equal to K. As the solution keeps concentrating, it remains at equilibrium with respect to the mineral but the activities of $\mathrm{A}$ and $\mathrm{B}$ cannot increase simultaneously. If $\mathrm{A}$ increases, $\mathrm{B}$ decreases and vice versa. Two cases may occur: if $(\mathrm{A})>(\mathrm{B})$, the activity of $\mathrm{A}$ keeps increasing and the activity of $\mathrm{B}$ decreases. If $(\mathrm{B})>(\mathrm{A})$, the activities evolve in the opposite direction. The above mentioned theoretical case applied to the precipitation of the calcite, allows the identification of both saline $((\mathrm{Ca})>($ Alk. $))$ and alkaline $(($ Alk. $)>(\mathrm{Ca}))$ evolution ways.

The use of the SAR adj instead of the SAR (Suarez, 1981, Ayers and Westcot, 1985) amounts to considering the solution at equilibrium with respect to the calcite instead of the bulk solution, i.e. shifting from point 1 to point 2 (or 1' to 2') in Fig. 2. However, the adjustment of the SAR does not take into account the evolution way during the concentration process, and yet again the sodicity hazard remains underestimated using this indicator in the case of solutions evolving in alkaline way. The adjustment of the SAR is a correct adjustment but it cannot be used as quantitative (multiplicative) factor for the assessment of the alkalisation hazard.

\section{The RSC :}

The concept of RSC is much closer to that of Residual Alkalinity, used in our article (Barbiero et al., 2001) and commented by Dr. Van Hoorn. RSC corresponds to RA calcite + $_{4}$ magnesite, i.e. Residual Alkalinity after the complete precipitation of $\mathrm{Ca}$ and $\mathrm{Mg}$ as carbonate salt. When the precipitation of $\mathrm{Ca}$ and $\mathrm{Mg}$ carbonates alone occurs without any other precipitation involving transfer of protons, the RSC can be used as a quantitative tool for assessment of sodicity hazard. However, $\mathrm{Ca}$ and $\mathrm{Mg}$ carbonates are usually not the only precipitate in natural waters therefore the RSC concept has its own limitation.

\section{Taking into account the precipitation of Mg:}


The precipitation of $\mathrm{Mg}$ as carbonate, not as magnesite but as $\mathrm{Mg}$-calcite, has been frequently observed. In the alkaline environment of Chad (Cheverry, 1974) or Niger (Barbiéro, 1995), the proportion of $\mathrm{Mg}$ ranges from 5 to $8 \%$, and $\mathrm{Ca}$ from 92 to $95 \%$. Such quantities are generally too low to explain the control of $\mathrm{Mg}$ in the solution. Moreover, the precipitation of $\mathrm{Mg}$ as silicate (stevensite, sepiolite, Mg-montmorillonite, palygorskite...) has been detected principally in alkaline environments (Tardy et al., 1974 ; Gac et al., 1977 ; Valles et al., 1989). However, the exact mineralogy of Mg-silicates is difficult to identify because of the low quantity of clay involved in the precipitation in comparison to the quantity of clay already present in the soil profile. Mg-clay formations involve transfer of protons, therefore they have an influence on the alkalinity, and should be logically included into the balance made on the Residual Alkalinity as developed in the referred article (Barbiéro et al., 2001). The calculation requires knowing the exact stoichiometry of the $\mathrm{Mg}$-silicate produced.

In the specific case of the Niger site, we took into consideration the precipitations occurring in the soil and not in the Niger river during evaporation for the assessment of water quality. The behaviour of $\mathrm{Ca}, \mathrm{Mg}$ and alkalinity in the soil solution during concentration is plotted on Fig. 3. The control of $\mathrm{Ca}$ (evolving in a 1/10 ratio) is much stronger than that of $\mathrm{Mg}$ (evolving in a 1/2 ratio) and the quantities of $\mathrm{Mg}$ involved (in both carbonate and silicate precipitations) are much lower than the alkalinity of the solution, and therefore do not significantly influence the control of alkalinity. The behaviour of $\mathrm{Mg}$ in the soil solution and the quantities involved do not justify the introduction of $\mathrm{Mg}$ precipitation in the assessment of salinity hazard of irrigation water. On the other hand, although fluoride amounts are not controlled during the concentration of Niger water, fluorite precipitation interferes significantly in the balance of alkalinity in the soil solution during evaporation and was therefore taken into account in the article, using $\mathrm{RA}_{\text {calcite+fluorite. }}$

\section{Final considerations}

Qualitative and quantitative assessment of salinity and/or sodicity hazard must be developed using several residual alkalinities that have to be adapted to each site according to the precipitations occurring in the soil (Valles et al., 1991) (Table 1).

In the Medjerdah valley, the irrigation water belongs to a saline calcic family. A neutral salinization will occur if irrigation is poorly managed; a leaching fraction must be applied in order to eliminate the salt brought at each irrigation. The agricultural problems are osmotic and toxicities with respect to $\mathrm{Na}, \mathrm{Cl}, \mathrm{B} \ldots$ The calcite + gypsum residual alkalinity, defined as $\mathrm{RA}_{\text {calcite+gypsum }}=(\mathrm{Alk})-.(\mathrm{Ca})+(\mathrm{SO} 4)$ can be used for quantification of salinity hazard.

The Mexican water belongs to a sulphate alkaline family. This water evolves in an alkaline way, but during evaporation the equilibrium with respect to the sodium sulphates is reached. The sodium amounts are controlled and remain moderate. No sodization of the complex will be observed in the soil. In this case, the agricultural problems are mainly osmotic. Two independent residual alkalinities can be used as tracer for the assessement of salinity hazard, the calcite residual alkalinity $\mathrm{RA}_{\text {calcite }}=(\mathrm{Alk})-.(\mathrm{Ca})$ and a thenardite residual alkalinity that could be defined as $\mathrm{RA}_{\text {thenardite }}=(\mathrm{Na})-(\mathrm{SO} 4)$ (Droubi et al., 1980).

The water of the Niger River belongs to a sodic alkaline family, which can induce a sodization of the soil complex, even for moderate concentration factors. Physical problems are expected, namely asphyxia, loss of structure, low permeability and hardsetting after drying (Sumner, 1993). $\mathrm{RA}_{\text {calcite }}$ usually presents a conservative behaviour during concentration and can be used as a conservative tracer. When $\mathrm{Mg}$ amounts are rather high and when $\mathrm{Mg}$ is involved in precipitation which consumes alkalinity, the $\mathrm{RA}_{\text {calcite+magnesite }}$ (or RSC) is a suitable tracer of the concentration process. However, in the case of Niger site, it is 
necessary to adapt the RA, using $\mathrm{RA}_{\text {calcite+fluorite }}=(\mathrm{Alk})-.(\mathrm{Ca})+(\mathrm{F})$ to take into account the concomitant precipitation of both calcite and fluorite.

As a conclusion, from the three concepts usually used for the assessment of sodicity hazard ( $\mathrm{SAR}, \mathrm{SAR}_{\text {adjusted }}$ and RSC), the RSC is the best one because it does not underestimate the hazard of carbonate irrigation water. The RSC concept is included in the RA concept, and our article described the conservative behaviour of the RA concept (Barbiéro et al., 2001) which was already applied in quantitative studies (Ribolzi et al., 1993, Ribolzi et al., 1996, Barbiero et al., 1995). Therefore, RA should support the development of new reliable criteria for assessment of irrigation waters in arid or semi arid regions.

\section{References}

Ayers, R.S, Westcot, D.W., 1985. Water Quality for Agriculture. FAO Irrigation and Drainage Paper 29, Rome, 174 pp.

Barbiéro, L., 1995. Les sols alcalinisés sur socle dans la vallée du fleuve Niger. Origine de l'alcalinisation et évolution des sols sous irrigation. Travaux et Documents Microfichés Orstom 138, 209 pp.

Barbiéro, L., Valles, V., Régeard, A. 1995. Contribution de la fluorine au contrôle géochimique du calcium sur un bas fond sahélien du Niger. Conséquences pour une estimation quantitative de l'évolution des sols. Comptes Rendus de l'Académie des Sciences, Paris 321, série II: 1147-1154.

Barbiéro, L., Van Vliet Lanoë, B., 1998. The alkaline soils of the Niger valley. Origins, formation and present evolution. Geoderma 84, 323-343.

Barbiéro, L., Valles, V., Regeard, A., Cheverry, C., 2001. Residual alkalinity as tracer to estimate the changes induced by a forage cultivation in a non-saline irrigated sodic soil. Agricultural Water Management 50, 229-241.

Cheverry, C., 1974. Contribution à l'étude pédologique des polders du lac Tchad. Dynamique des sels en milieu continental subaride dans les sédiments argileux et organiques. Thesis. Sci., U.L.P. Strasbourg, 257 pp.

Droubi, A., Fritz, B., Gac, J.Y., Tardy, Y., 1980. Generalized residual alkalinity concept application to prediction of the chemical evolution of natural waters by evaporation. American Journal of science 280, 560-572.

Eaton, F.M., 1950. Signifiance of carbonates in irrigation waters. Soil Science 69, 123-133.

Gonzalez Barrios, J.L., 1992. Eau d'irrigation et salinité des sols en zone aride mexicaine. Exemple de la Comarca Lagunera. Ph.D. Thesis USTL (Montpellier II), 316 pp.

Ribolzi, O., Vallès, V., Barbiéro, L., 1993. Contrôle géochimique des eaux par la formation de calcite en milieu méditerranéen et en milieu tropical. Arguments d'équilibre et argument de bilan. Science du Sol 31 (1/2), 77-95.

Ribolzi, O., Valles, V., Bariac, T., 1996. Comparison of hydrograph deconvolutions using residual alkalinity, chloride and oxygen 18 as hydrochemical tracers. Water Research Resource 32 (4), 1051-1059

Richards, L.A., 1954. Diagnosis and improvement of saline and alkali soils. USDA agric. Handbook 60, Washington, $160 \mathrm{pp}$.

Suarez, D.L., 1981. Relations between pHc and Sodium Adsorbtion Ratio (SAR), and an alternative method for estimating SAR of soil and drainage waters. Soil Science Society of America Journal 45, 469-475.

Sumner, M.E., 1993. "Sodic soils ”, new perspectives. Australian Journal of Soil Research 31, 683-750.

Tardy, Y., Cheverry, C., Fritz, B., 1974. Néoformation d'une argile magnésienne dans les dépressions interdunaires du lac Tchad. Application aux domaines de stabilité des 
phyllosilicates alumineux, magnésiens et ferrifères. Comptes Rendus de l'Académie des Sciences, Paris, t 278, série D, 1999-2002.

Gac, J.Y., Droubi, A., Fritz, B., Tardy, Y., 1977. Geochemical behaviour of silica and magnesium during the evaporation of waters in Chad. Chemical geology 19, 215-228.

Valles, V., 1987 - Etude et modélisation des transferts d'eau et de sel dans un sol argileux. Application au calcul de doses d'irrigation. Science Géologique Mémoire 79, 148 p.

Valles, V., N'Diaye, M.K., Bernadac, A., Tardy, Y., 1989. Geochemistry of water in the Kouroumari region, Mali. $\mathrm{Al}, \mathrm{Si}$ and $\mathrm{Mg}$ in water concentrated by evaporation: development of a model. Arid Soil Research and Rehabilitation 3, 21-39.

Valles, V., Pachepsky, I., Ponizovsky, A.A., 1991. Ivariant criteria for irrigation water quality assessment in arid and semi-arid regions. In : Genesis and Control of Fertility of Salt Affected Soils : ISSS Subcommission on Salt Affected Soils Science, pp. 330-333 USSR, V.V. Dokuchaev Soil Institute, Moscow.

\section{Figure captions}

Fig. 1 : Advance of SAR and EC during a pan evaporation experiment of three irrigation waters from Mexico, Tunisia and Niger.

Fig. 2: Theoretical advance of a solution reaching equilibrium with respect to a mineral $A B$, in a $\log (\mathrm{A})$ versus $\log (\mathrm{B})$ diagram.

Fig.3 : Concentration diagram of alkalinity, calcium, and magnesium in the soil solution from brown soil to sodic soil in Niger (modified from Barbiéro and Van Vliet Lanoë, 1998). 


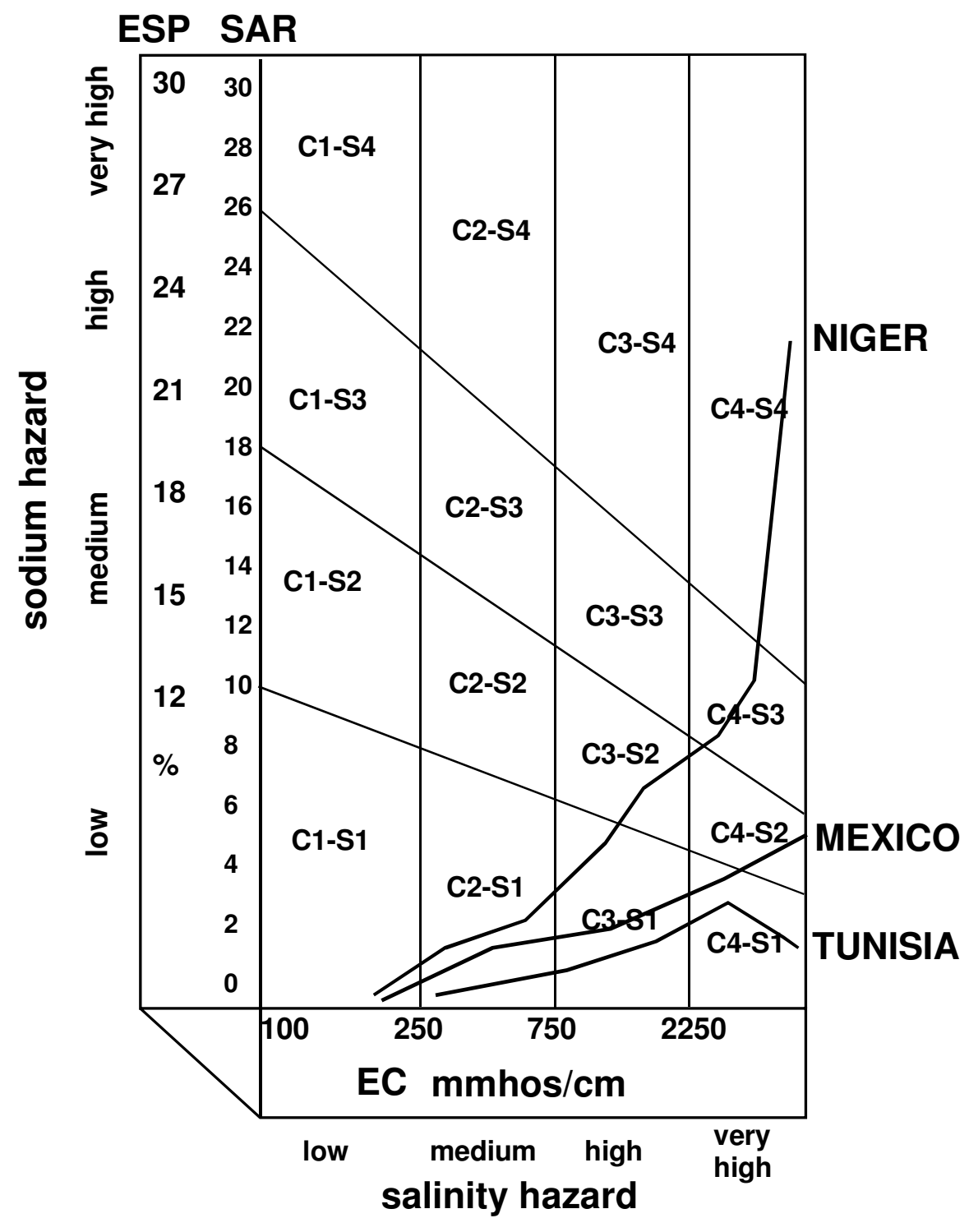




\section{$\log (A)$}

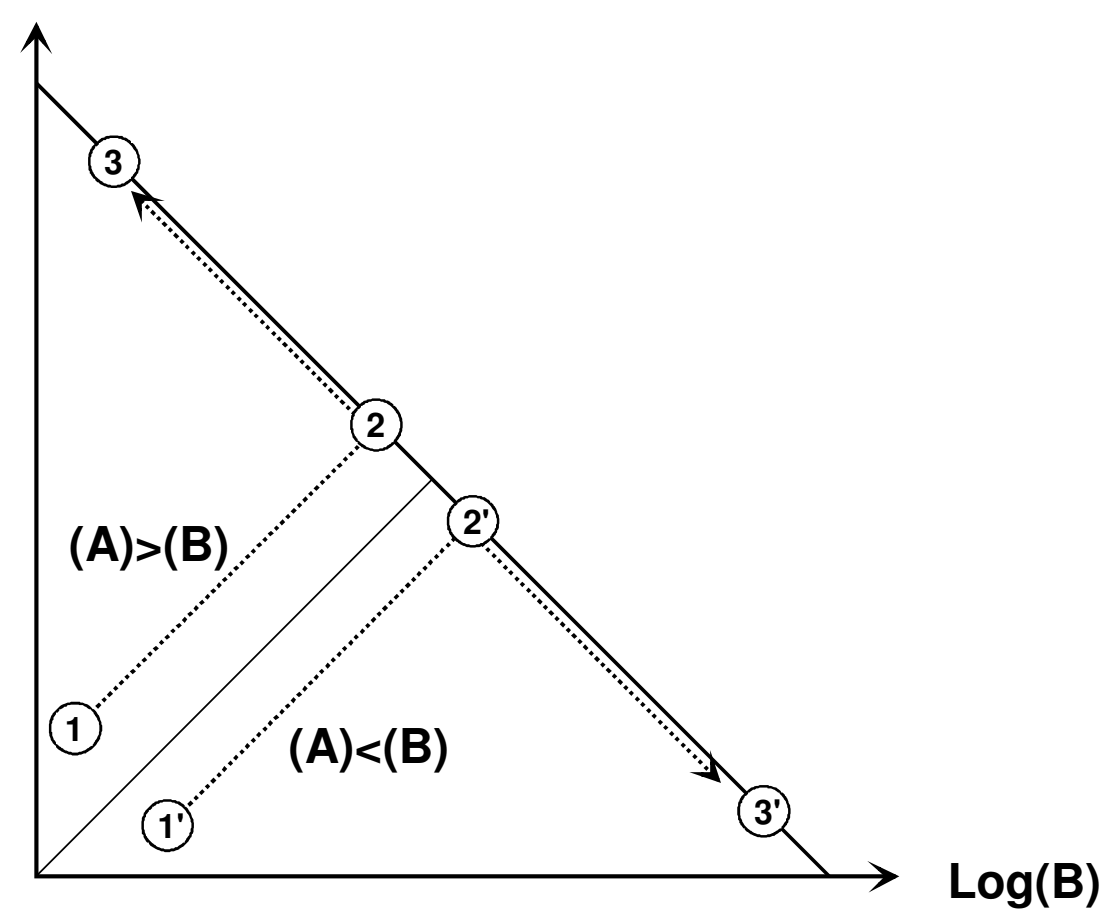

$\log$ (molality)

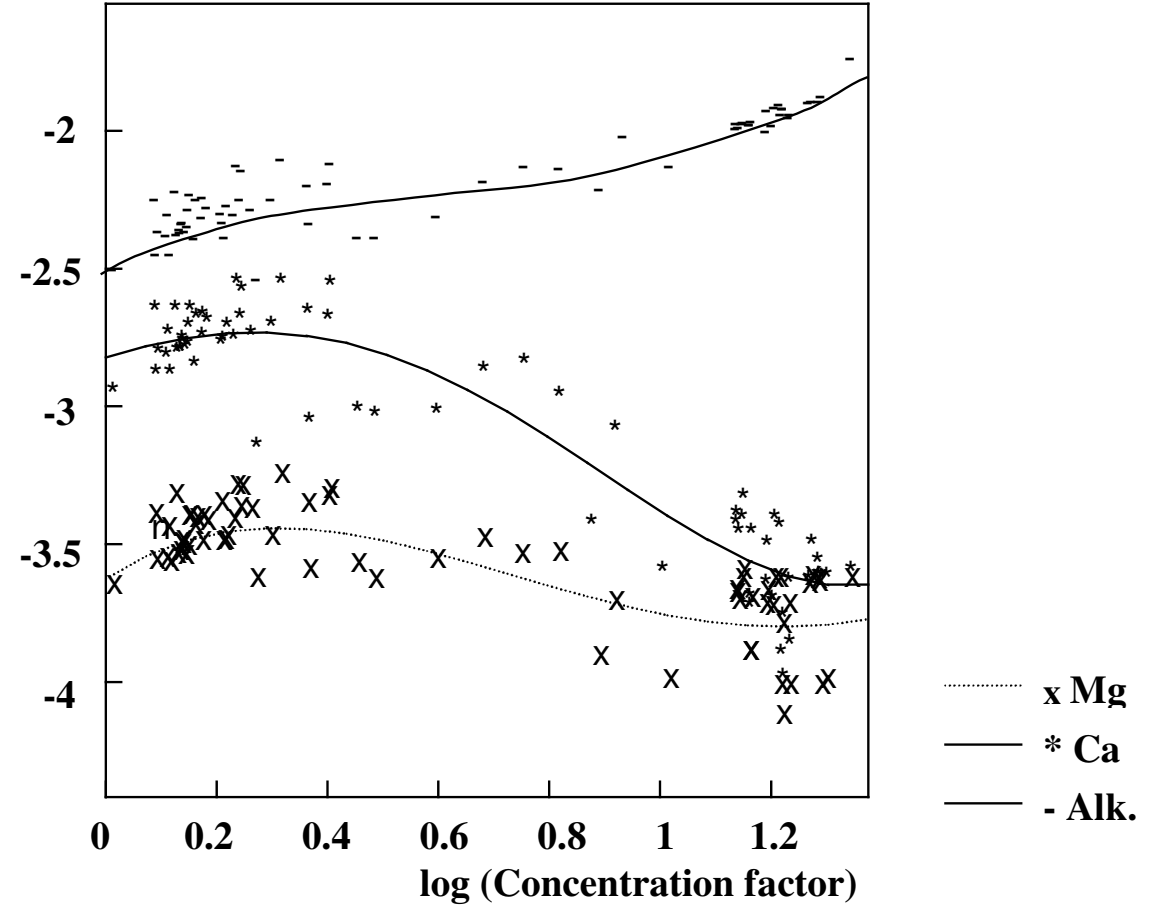


Table 1: Subdivision of irrigation water of arid and semi-arid area into 5 families (modified from Valles et al., 1991).

\begin{tabular}{|c|c|c|c|c|}
\hline \multirow{2}{*}{$\begin{array}{c}\text { Alk }<0 \\
\text { Acid } \\
\text { group }\end{array}$} & \multicolumn{3}{|c|}{ Alk $>0$} \\
\cline { 2 - 5 } & \multicolumn{2}{|c|}{$\begin{array}{c}\text { Alk. }-\mathrm{Ca}<0 \\
\text { Saline group }\end{array}$} & \multicolumn{2}{c|}{$\begin{array}{c}\text { Alk. }-\mathrm{Ca}>0 \\
\text { Alkaline group }\end{array}$} \\
\hline & $\begin{array}{c}\text { Alk. }-\mathrm{Ca}+\mathrm{SO}_{4} \\
<0\end{array}$ & $\begin{array}{c}\mathrm{Alk} .-\mathrm{Ca}+\mathrm{SO}_{4} \\
\mathrm{Na}-\mathrm{SO}_{4}<0\end{array}$ & $\mathrm{Na}-\mathrm{SO}_{4}>0$ \\
$(1)$ & $(2)$ & $(3)$ & $(4)$ & $(5)$ \\
Acid & Calcic & Sulfate & Sulfate & Carbonate \\
family & Saline & saline & alkaline & alkaline \\
& family & family & family & family \\
\hline
\end{tabular}

